\title{
Word order change at the left periphery of the Hungarian noun phrase
}

\author{
BARBARA EGEDI
}

\subsection{Introduction}

This chapter aims to give an account of the change that can be observed in the structure of the Hungarian noun phrase from the first written sources to the present day, with a special focus on determination and possessive constructions, i.e. the nominal left periphery. Analysing the historical data, a possible scenario will be offered as to how the functional extension of the noun phrase develops in a language, apparently inevitably, after the overt marking of definiteness grammaticalized and its use expanded. Three steps (or states) of the so-called definiteness cycle can clearly be identified from Old Hungarian to modern times: the appearance of the article in welldefined contexts, the emergence of a new type of demonstrative modification, and the reintegration of the adjoined demonstrative pronouns into the DP domain. Word order variation arises due to the determiners' interference with the possessor expressions at the left periphery of the noun phrase.

Following this general introduction, the essential characteristics of the noun phrase in present-day Hungarian will be discussed in section 5.2, relying on current generative analyses. In the subsequent section, the noun phrase in Old Hungarian will be described and its structure reconstructed. This section also reviews the historical language stages of Hungarian to provide the fundamental background information about the sources on which this study has been built. Finally, through the presentation of some peculiar Middle Hungarian word order phenomena, an overall reconstruction of the structural change at the nominal left periphery will be proposed and, accordingly, the word order change from Demonstrative-PossessorPossessum into Possessor-Demonstrative-Possessum will be accounted for. The study concludes by summarizing the word order variation and change thus far discussed in a schema of the various patterns. 


\subsection{The noun phrase in Modern Hungarian}

The literature on the Hungarian noun phrase is rather rich: a detailed analysis in a generative framework can be found in Szabolcsi (1994), which has been modified to some extent by É. Kiss (2000) and Bartos (2000, 2001). Of course, not all aspects of the noun phrase structure will be discussed here; several features, such as the inner agreement properties, or the derivation of attributes and quantifiers, will be ignored. The focus of this study primarily falls on possessive constructions and demonstratives, and their interaction at the left periphery of nominal constructions.

\subsubsection{Demonstratives}

Demonstrative modifiers behave rather interestingly in Modern Hungarian, that is to say, they are not prototypical deictic determiners. Demonstratives co-occur with the definite article, and unlike other Hungarian modifiers, they agree in number and case with the head noun.
(1) a. ez-ek a könyv-ek
this-PL the book-PL
'these books'
b. az-t a könyv-et
that-ACC the book-ACC
'that book'
c. az-ok-at a könyv-ek-et
that-PL-ACC the book-PL-ACC
'those books'

According to the above-mentioned generative analyses there are good reasons to assume that the demonstratives (ez/az'this/that') are located in the specifier position of the DP projection (2), rather than being adjoined constituents, even though the definite article is also spelled out in the head of the same phrase. This goes against the well-known economy principle established for functional projections, and still there are good arguments for a doubly filled DP analysis: nothing can intervene between the demonstrative and the article, the construction is not grammatical without spelling-out the article, and the two determiners also form a prosodic unit (cf. Bartos 2000, 2001; as far as I know this placement of the demonstrative modifier was first pointed out by Kenesei 1999: 295):

(2) a. [DP ez/az [D’a [NumP három [NP könyv] ]]]

b.

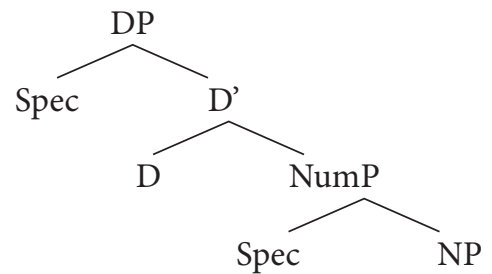

ez/az a három könyv

this/that the three book

'these/those three books' 
As will be shown at a later point in the discussion, the conditions, however, were slightly different when this pattern arose in the Middle Hungarian period.

\subsubsection{Possessives}

In Hungarian, there are two types of possessor expressions: a dative-marked (3a) and a nominative/unmarked ( $3 \mathrm{~b}$ ) - with no actual difference in meaning. (The gloss 'poss' in the examples stands for the suffix on the head noun that encodes its being possessed.)

(3) a. a szerzetes-nek a könyv-e
the monk-DAT the book-Poss
b. a szerzetes köny-e
the monk book-Poss

The syntactic positions of the possessor expressions are claimed to be different. This is suggested by two main features (as has been pointed out by Anna Szabolcsi 1994: 180-1): (i) by the presence/absence of the article between the two members of the constructions; and (ii) by the fact that dative-marked possessors can be extracted from the noun phrase. This latter means that the dative-marked possessor can appear outside the noun phrase, disconnected from the possessed noun by other constituents of the sentence, as a kind of external possessor. Unmarked possessor expressions cannot be extracted in this way.

Following Szabolcsi's analysis, É. Kiss (2000: 134) claims that the possession marker on the noun licenses the possessor as an argument. This possessor-argument is realized either as a dative case marked complement, or as a pre-nominal specifier bearing no case at all. The caseless possessor can only survive if it has a [+determiner] feature and moves to the DP domain to have it checked. The presence/absence of the article follows from the difference between the two constructions. The caseless possessor in (3b) moves directly into Spec,DP and, consequently, the head of the DP cannot be filled by the article. Actually, we never find a definite article in the constructions of type ( $3 b){ }^{1}$ On the other hand, the possessor in (3a) has to leave its post-nominal complement position for the so-called Case Constraint ${ }^{2}$ and must undergo noun phrase internal topicalization, landing in a phrase-initial specifier position (Spec,TopP). This derivation can be observed in (4). Note, that the notion of a DP-internal Topic phrase was introduced by Katalin É. Kiss in her 2000 paper only, while in her earlier works this movement operation was considered to be an adjunction to DP.

\footnotetext{
1 The asymmetry is obvious: in the case of lexical possessors the DP cannot be doubly filled, while in the case of demonstratives the simultaneous filling of the head and the specifier even seems to be required, as has been presented above. This phenomenon remained an unsolved contradiction in the generative literature on present-day Hungarian. Even though it shows to be a challenge in the synchronic description, however, viewing the problem from a diachronic perspective may shed some light on the question as to how this asymmetry emerged (see section 5.4)

2 The Case Constraint is formulated as follows: (i) the case suffix must cliticize to the right edge of the noun phrase; (ii) the case suffix cannot cliticize to a case marked stem. These constraints can only be satisfied if a post-nominal complement is extraposed, or if it is realized in the form of a modifier (É. Kiss 2000: 127). Not only are possessive constructions subject to this rule, but any nominal expressions that can take a argument will meet the case.
} 
(4)

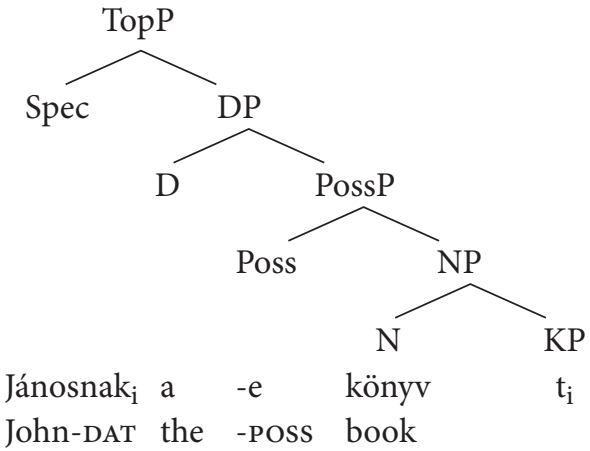

(After É. Kiss 2000:139)

John-DAT the -POSS book

In this case, the definite article freely co-occurs with the possessor, and so does the demonstrative, since the dative-marked possessor is located in Spec,TopP, rather than in Spec,DP.

It is important to note, and it also follows from the derivation in (4), that if both a demonstrative and a possessor are present in the construction (5), the possessor must always precede the demonstrative which is located in Spec,DP. (5b) is therefore ungrammatical. So is $(5 \mathrm{c})$ with its unmarked/caseless possessor expression, since this latter competes with the demonstrative for the same structural position (SpecDP). The structure in (6) corresponds to the grammatical word order exemplified in $(5 a)$.

(5) a. a szerzetes-nek ez a könyv-e the monk-DAT this the book-POss 'this book of the monk'

b. *ez a szerzetes-nek a könyv-e this the monk-DAT the book-POSS Intended meaning: 'this book of the monk'

c. *a szerzetes ez a könyv-e the monk this the book-Poss Intended meaning: 'this book of the monk'

(6)

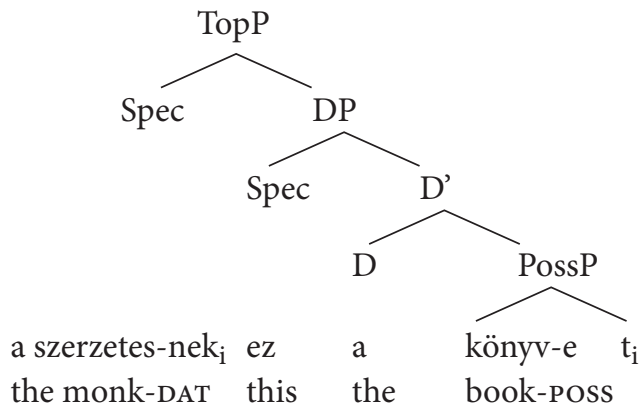

\subsection{The noun phrase in Old Hungarian}

Before turning to the historical data, a few basic facts are to be mentioned with respect to the nature and the date of the sources which are used throughout this 
study. The following table summarizes the most important information related to the historical linguistic stages of Hungarian: the time intervals and the types of sources we have from the various periods.

TABLE 5.1. Historical language stages of Hungarian and types of sources

\begin{tabular}{|c|c|c|c|}
\hline \multicolumn{2}{|c|}{ Proto-Hungarian } & $1000 \mathrm{BC}-896 \mathrm{AD}$ & no written documents \\
\hline \multirow{2}{*}{$\begin{array}{l}\text { Old } \\
\text { Hungarian }\end{array}$} & $\begin{array}{l}\text { Early Old } \\
\text { Hungarian }\end{array}$ & $896-1370$ & $\begin{array}{l}\text { sporadic records, glosses, a few short texts, } \\
\text { e. g. Funeral Sermon and Prayer (c.1195) }\end{array}$ \\
\hline & $\begin{array}{l}\text { Late Old } \\
\text { Hungarian }\end{array}$ & $1370-1526$ & $\begin{array}{l}\text { mainly codices; translations of Latin } \\
\text { religious literature }+ \text { original Hungarian } \\
\text { compositions }\end{array}$ \\
\hline \multicolumn{2}{|c|}{ Middle Hungarian } & $1526-1772$ & $\begin{array}{l}\text { Book printingNew secular } \\
\text { genresSignificant increase in quantity }\end{array}$ \\
\hline
\end{tabular}

Distinguishing between the Early and the Late Old Hungarian period is relevant because of the nature of the sources that come from these two periods. The first written sources can be dated to the Early Old Hungarian period, but these are sporadic records, mostly names of people and places and other glosses embedded in Greek or Latin documents and charters. The first continuous texts from the same period (dating from between the end of the twelfth century to the end of the thirteenth century) are short and do not form a uniform corpus either in time or in space. One of the four records is fragmentary and two of them are not even narrative. Accordingly, the first texts of considerable length and suitable for a syntactic investigation come from the first half of the Late Old Hungarian period, in the form of the first Hungarian codices. ${ }^{3}$ These, for the most part, contain translations of Latin religious literature, ${ }^{4}$ but they are long enough, each forming a closed, uniform corpus of its own.

\subsubsection{Demonstratives and articles}

The grammatical encoding of referential identification in the Old Hungarian period appears to comprise a different system, as compared to the one used at the present time (for a detailed study on this topic, see Egedi 2013). Modern Hungarian makes

\footnotetext{
${ }^{3}$ For more details about the first continuous texts from the Early Old Hungarian period (beginning with the Funeral Sermon and Prayer) and about the earliest codices, see Egedi (2014a: 61-4).

4 The possible influence of the source language on Hungarian word order phenomena has been kept in mind throughout this research. Moreover, it has been concluded for the language of the Old Hungarian codices in general, that the influence of Latin can only be detected in terms of quantity rather than in terms of quality. This means that if Hungarian grammar allowed the use of alternative structures to express a certain content, the early translators were inclined to choose constructions that appeared to be closer to the original text. No doubt, some of the passages read quite unnaturally in a stylistic sense, but the grammar itself seems not to have been affected by the Latin syntactic structures. (The issue has been summarized in a paper written in Hungarian: Egedi 2014b.)
} 
extensive use of the definite article. As can be observed in examples ( 7 ) and (8), the article obligatorily occurs together with demonstratives and with a dative-marked possessor. The corresponding Old Hungarian examples, however, look rather different since the definite article is absent in the same contexts. Consider (9) and (10) to see contrast.

Modern $\mathrm{D}$ rian

(7) ez/az a könyv

this/that the book

'this/that book'

(8) a szerzetes-nek $a$ könyv-e

the monk-DAT the book-poss

'the book of the monk'

Old Hungarian

(9) $\mathrm{e}(\mathrm{z}) / \mathrm{a}(\mathrm{z})$ ø könyv

this/that book

'this/that book'

(10) a(z) szerzetes-nek ø könyv-e

the monk-DAT book-pOss

'the book of the monk'

As a result of my earlier investigations, it may be concluded that the marking of pragmatic definiteness on a syntactic level is already obligatory at the time of the first codices, but the definite article only appears in the cases where the referential identification is not encoded otherwise. Therefore, among other contexts, it is absent with nouns modified by a demonstrative, which encodes directly accessible reference, and in possessive constructions, in which the referent of the possessed noun is existentially presupposed and is identified through its relation to the referent of the possessor. ${ }^{5}$ To put it differently, the presence of a demonstrative (9) or a possessor expression (10) can imply the definiteness of the noun phrase as a whole, and the use of the article is not yet required.

The situation was changing quite rapidly, although not in an equal manner in all the possible contexts, as recent research has demonstrated (Egedi and Simon 2012). ${ }^{6}$ An automatic query carried out in five normalized codices from the Old Hungarian Corpus showed that the use of the definite article proportionally increased already within the Old Hungarian period (cf. Table 5.2), but the spreading can only be detected in certain contexts (such as generics or before pronominal possessors),

\footnotetext{
5 There are detailed arguments for the Old Hungarian definite determiner functioning as a true article and being a fully grammaticalized category encoding pragmatic definiteness in the already cited paper (Egedi 2003). The identification of definite contexts in which the article is still absent is also discussed there.

6 The results of the query presented in 2012 have been updated several times, which slightly modified the numerical data. Table 5.2 has been synchronized with the table that can be found in Egedi (2014a: 66).
} 
OUP UNCORRECTED PROOF - FIRST PROOF, 8/1/2018, SPi

TABLE 5.2. The proportion of definite determiners $(a / a z)$ in five Old Hungarian codices

\begin{tabular}{llrrr}
\hline Codex & Date & Tokens & a/az & $\%$ \\
\hline Jókai Codex & after 1370/c.1448 & $\mathbf{2 2 , 7 3 3}$ & 573 & $\mathbf{2 . 5 2}$ \\
Vienna Codex & after 1416/c.1450 & 54,423 & $\mathbf{2 , 2 3 3}$ & $\mathbf{4 . 1}$ \\
Guary Codex & before 1495 & 21,714 & 1,390 & $\mathbf{6 . 4 0}$ \\
Booklet & 1521 & 8,745 & 623 & 7.12 \\
Kazinczy Codex & $1526-41$ & 20,027 & 1,437 & 7.17 \\
\hline
\end{tabular}

while the contexts relevant here (nouns with demonstratives and lexical possessors) resisted the determiner all along the period. Constructions such as those illustrated in (7) and (8) only appear during the Middle Hungarian period and therefore will be discussed in the next section.

It is to be noted that the Hungarian definite article developed from a demonstrative modifier, as also happened in many other unrelated languages, but in this early period these two elements, the distal demonstrative and the definite article cannot be distinguished merely on formal grounds. The modern reader sometimes remains uncertain how to interpret an Old Hungarian phrase such as (11a-b) because the article and the distal demonstrative modifier look exactly the same, have the same position and also show some functional overlap (e.g. anaphoric use).

$\begin{aligned} & \text { (11) a. az kapu } \\ & \text { the gate } \\ & \text { b. az kapu } \\ & \text { that } \text { gate }\end{aligned}$

Depending on the context, the morpheme 'az' sometimes seems to behave as a demonstrative, sometimes as a definite article, and often it is impossible to decide between the two options. ${ }^{7}$ The only exceptions to this ambiguity are the clear semantic or pragmatic contexts in which only an article can appear, such as the larger situational use, or the associative-anaphoric use, in terms of Himmelmann (2001).

Despite this homophony, the article and the distal demonstrative can be assumed to occupy distinct structural positions, D and Spec,DP, respectively. The emergence of the definite article may be reconstructed similarly to what Giuliana Giusti (2001: 167) proposes for the reanalysis of the Latin determiner ille in the Romance

\footnotetext{
${ }^{7}$ Hence it is not completely unexpected that there is a tendency in the descriptive tradition of Old Hungarian to consider these determiners as 'pre-articles', or 'pronoun-articles', representing a transitional word-class with dual nature (Bakró-Nagy 1999: 7; I. Gallasy 1992: 721-2). For the same problem in Old English, see, among others, Sommerer (2011) with further references.
} 
languages. As is illustrated in (12), ille, originally located in the specifier of the Determiner Phrase as a demonstrative, is reinterpreted as an element in D.

(12) a.

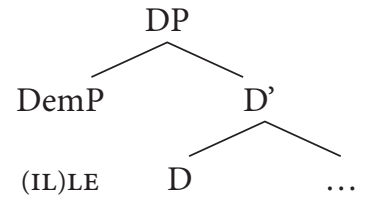

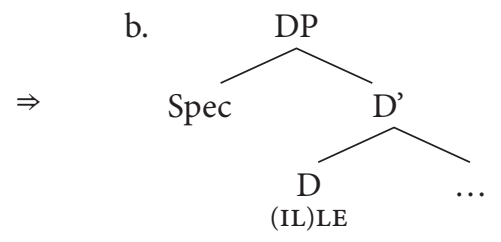

This kind of reanalysis perfectly fits with one of the economy principles formulated by Van Gelderen (2004, 2008b), the so-called 'Head Preference Principle', according to which speakers prefer to build structures where an element is merged directly into the head position instead of moving it to the specifier from below.

The two constructions in (12) may also have coexisted in the language for several generations. Nevertheless, to avoid ambiguity, new lexical items developed to fulfil the demonstrative function in Romance: an adverbial reinforcer has been added to the phonologically weakened demonstrative head resulting in a new series of deictic elements. Interestingly enough, in Hungarian, the homophonous structures split in a different way, resulting in a somewhat surprising word order variation on the nominal left periphery. This problem will be addressed in section 5.4 on Middle Hungarian.

\subsubsection{Possessives}

As was presented in section 5.2.2, Hungarian has two kinds of possessor expressions, dative-marked and unmarked. Although the same holds for Old Hungarian, it is worth examining whether the characteristics of these possessors correspond to those established for their Modern Hungarian descendants.

As far as possessor extraction is concerned, the existence of extracted constituents could be tested and justified by an automatic query in the digitized Old Hungarian Corpus. More precisely, the search has been completed for one of the early codices, namely in Jókai Codex, which has also been morphosyntactically annotated, thus it can be more reliable to probe. After having also examined manually all the examples in the selected manuscript, out of 756 possessive constructions in which the possessor is dative-marked, 21 external possessors were found.

TABLE 5.3. Positions of dative-marked possessors in Jókai Codex

\begin{tabular}{lr} 
Constructions with dative-marked possessors in the text & 756 \\
\hline Possessor and possessed noun are adjacent & 613 \\
Possessor and possessed noun are separated by attributes, or quantifiers & 122 \\
Possessor extracted out from the NP & $\mathbf{2 1}$ \\
\hline
\end{tabular}


The presence/absence of an article between the two members of the possessive construction is not a distinctive feature in Old Hungarian. As was stated in the previous section, the use of the definite article is more restricted in this period, being redundant in the contexts where reference is identified by another entity. Thus, as expected, the definite article never appears before the possessed noun in either of the constructions. This phenomenon has also been tested in the five normalized codices listed in Table 5.2. I attested zero occurrence of the article between a caseless possessor and its possessum in constructions such as (13b), and fewer than ten occurrences between a dative-marked possessor and its possessum in constructions such as (13a).

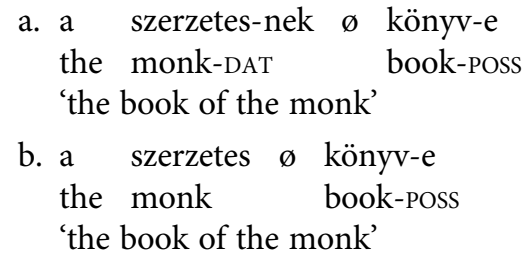

So the opposition shown in (3) for Modern Hungarian does not hold in Old Hungarian.

Undoubtedly, the morphologically marked possessor must have emerged in ProtoHungarian (or rather reanalysed from an 'affected' constituent, cf. É. Kiss 2014 for modern Hungarian) to encode extracted or external possessors. The external position of the dative-marked possessor can still be observed in sporadic examples, where an overt and coreferent NP/DP-internal possessive pronoun co-occurs with the lexical possessor. By the documented era, however, the variation presented in (13) is widespread, with no interpretive difference. Accordingly, there is no reason to assume, on a synchronic level, that the Old Hungarian dative-marked possessor could not occupy Spec,DP in these cases. (Of course, when the dative-marked possessor is separated from the possessum, there are still two possibilities: it has been extracted out of the $\mathrm{NP} / \mathrm{DP}$ and is co-indexed with a pro, or else, it is really external, which means that it has been generated outside the DP.) What the data suggest at this point of the analysis is that while unmarked possessors always occupy the specifier of the DP, dativemarked possessors can freely appear both in an external and in an internal position and, in the latter case, they are located in Spec,DP as well.

The assumption that both types of Old Hungarian possessor expressions prefer the Spec,DP position is supported by a remarkable observation: possessives and demonstratives seem not to be attested together in this period, suggesting that they mutually exclude each other. Does it mean that these expressions occupy the same structural position? It is really interesting to observe how the Old Hungarian codices and an early printed book from the beginning of the Middle Hungarian period translated the Latin phrase of Matthew 24:14, which contains the rare combination of a possessor and a demonstrative modifier. They all apply various avoidance strategies by ignoring the deictic element, or by transforming the possessive relation into an attributive construction or a relative clause: 
Gospel of Matthew 24:14: ${ }^{8}$

(14)

a. Latin
Et praedicabitur hoc evangelium regni in universo orbe
and will.be.preached this gospel kingdom-GEN in whole.ABL world.ABL

b. King James Version of the Bible

And this gospel of the kingdom shall be preached in all the world

c. Munich Codex [1466] $\rightarrow \quad$ ignores the demonstrative

És prédikáltatik az ország-nak evangéliom-a mend ez világ-ban and be.preached the kingdom-DAT gospel-POss all this world-INE

d. Jordánszky Codex [1516-19] $\rightarrow \quad$ attribute instead of a possessor És prédikáltatik ez mennyei szent evangéliom mind ez teljes and be.preached this heavenly holy gospel all this whole világ-on world-sup

e. New Testament of Pesti Gábor [1536] $\rightarrow \quad \rightarrow \quad$ relative clause És ez evangéliom, ki mennyből vagyon, hirdettetik and this gospel which heaven.ABL is be.preached

\subsection{Middle Hungarian phenomena}

\subsubsection{Demonstratives}

By the expansion of the use of the article in semantically definite contexts, such as generic readings and nouns with an inherently unique referent, the increased frequency of the spelling out of the D head led to successive reanalyses at the left periphery of the noun phrase. During the sixteenth century, in the Middle Hungarian period, a new pattern arises for the noun phrases containing a demonstrative. In this structure a sort of determiner doubling can be observed, which seems to be identical—at least at first sight-to the construction we have in Modern Hungarian, where the functional projection for definiteness is doubly filled. This means that the demonstrative is spelled out in the specifier position, while the determiner functioning as an article is in the head of the DP (cf. examples in (1) and the tree in (2)).

Observing the historical data, however, a distinct synchronic state can be identified in which word order patterns at the nominal left periphery differ from those established in section 5.2. In the sixteenth and seventeenth centuries, the newly added demonstrative can be separated from the rest of the construction by various elements, e.g. particles, conjunctions, sometimes by the verb itself, which means that it links more loosely with the noun phrase in Middle Hungarian than it does today. (15a) and (16a) are examples from the first half of the seventeenth century (taken from the

\footnotetext{
8 The Latin source is included in the text edition of the Old Hungarian translations. The King James Version of the Bible is available at $<\mathrm{http}$ ://www.biblegateway.com $>$.
} 
descriptive grammar of Simonyi 1914: 122-3), while in (15b) and (16b) alternative word orders are presented in order to show how these phrases would look in Modern Hungarian. In the Middle Hungarian data, the sequence of the demonstrative and the definite article is broken: in (15a) a scalar particle intervenes, while in (16a) an interrogative particle comes in between.

(15) a. azok is az esküvések

(Pázmány Five letters 131) those also the swearings 'also those swearings'

b. azok az esküvések is those the swearings also 'also those swearings'

a. Mit választasz inkább? what choose-you more?

ezt-e

a pénzt? 'What do you prefer to choose? This money?'

(Káldi Preachings 209)

$\begin{array}{lll}\text { b. ezt a pénzt-e } & \\ \text { this.ACC } & \text { the money.ACC-INT.PRT }\end{array}$

To account for the Middle Hungarian data and for their different appearance with respect to their modern counterparts, it seems plausible to assume that the determiner doubling construction is the outcome of an adjunction operation, where the demonstrative pronoun as a whole adjoins to the DP headed by an article:

$$
\begin{array}{rll}
{\left[{ }_{D P}^{[D P} \text { ez-t }\right]} & {\left[{ }_{D P} \text { a pénz-t }\right]} \\
\text { this-ACC } & \text { the money-ACC }
\end{array}
$$

It is to be noted that the spread of the new pattern in the Middle Hungarian period does not show the same degree with the proximal and the distal demonstrative modifier. The proximal demonstrative 'ez' differs from the article in its form, causing no ambiguity of the kind illustrated in (11). As the figures in Table 5.4 indicate, the doubling construction with 'ez' is much less frequently attested in the entire period and its spreading is definitely slower than that with the distal demonstrative.

TABLE 5.4. The spread of the constructions 'ez/az az N'

\begin{tabular}{lrrrc}
\hline & 16 th c. & 17 th c. & 18 th c. & For the entire period \\
\hline 'az az N' & $54.5 \%$ & $91.7 \%$ & $92.6 \%$ & $85.5 \%$ \\
'az N' & $45.5 \%$ & $8.3 \%$ & $7.4 \%$ & $14.5 \%$ \\
\hline & 16 th c. & 17 th c. & 18 th c. & For the entire period \\
\hline 'ez az N' & $3.8 \%$ & $21.5 \%$ & $40.8 \%$ & $20.4 \%$ \\
'ez N' & $96.2 \%$ & $78.5 \%$ & $59.2 \%$ & $79.6 \%$ \\
\hline
\end{tabular}

(Figures after Dömötör 2008: 24-5) 


\subsubsection{Possessives}

In line with the tendency of the more and more frequent spelling out of the $\mathrm{D}$ head by means of an article, the definite article started to precede a possessed noun with a dative-marked possessor as well. This means that patterns exemplified in (3a) and (8) are getting to be attested from the Middle Hungarian period. As for the structure behind this emerging pattern, dative-marked possessors may be assumed to adjoin to the DP as a whole (just the same way as demonstratives do, cf. (17)), if one accepts the claim that the simultaneous filling of the $\mathrm{D}$ head and its specifier is not preferred.

As demonstrated in section 5.3, dative-marked possessors can regularly appear detached from the noun phrase as early as in the first continuous manuscripts, thus an extracted or external possessor can easily be reanalysed as an adjoined constituent in Middle Hungarian (18a). Nevertheless, the Old Hungarian possessive construction with no article before the possessed noun (18b) remains available and survives besides the new pattern.

$$
\begin{aligned}
& \text { a. [DP [DP a szerzetes-nek] [DP a könyv-e]] } \\
& \text { the monk-DAT the book-pOss } \\
& \text { b. [DP a szerzetes-nek [D’ } \varnothing \text { [könyv-e]] } \\
& \text { the monk-DAT book-POSS }
\end{aligned}
$$

Remarkably, unlike in Old Hungarian, the combination of demonstratives and possessives becomes well attested in this period, but at the same time shows a peculiar distribution in which the demonstrative precedes the possessor expression, as exemplified in (19) to (21) — the data in (20) and (21) are taken again from Simonyi (1914):

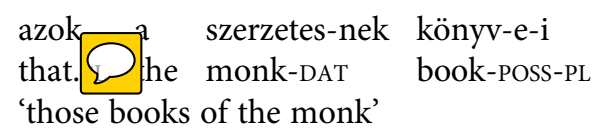

(20) az-ok az Angliá-nak nemes-e-i (Faludi 63) that-PL the England-DAT nobleman-POSS-PL 'those noblemen of England'

(21) ar-rul is az bibliá-nak rész-é-rül that-DEL also the Bible-DAT part-POSS-DEL 'also about that part of the Bible'

These word orders, with the demonstrative on the left and the possessor inside, would be completely ill-formed in Modern Hungarian (cf. examples in (5)).

Because of the fact that, at this point of the research, Middle Hungarian texts have not been digitized and data could only be collected manually, it is not clear when the Modern Hungarian word order (Poss Dem) appeared. Neither can we provide any numerical data about the proportion of the peculiar Dem Poss word order. (The combination is extremely rare in every period for obvious semantic reasons.) The question to be raised in the present analysis is how this word order variation can be accounted for.

The possibility of a more extended noun phrase evidently emerged in this period, but while the $\mathrm{D}$ head is more and more systematically occupied by the definite article, 
the position of the dative-marked possessor and the demonstrative, two expressions of quite different nature, have not become fixed yet.

The situation may be reconstructed in the following way. When the determiner doubling construction emerged in Middle Hungarian, the demonstrative (showing agreement in case and number with the noun) adjoined either to the noun phrase headed by the definite article (as in (17)), or to the old, articleless and a more condensed possessive structure ( $18 \mathrm{~b}$ ), but it did not adjoin to the possessive structure in which the possessor expression was also 'external' (18a) - at least, the author does not know of such occurrences. The combination of the new loosely adjoined demonstrative with (18b) is illustrated below (an accusative case ending has been added to make the agreement noticeable):
a. $[\mathrm{DP}[\mathrm{DP}$
az-t $] \quad[\mathrm{DP}$ a
szerzetes-nek [D’ ø [ könyv-é-t]]]
that-ACC the
monk-DAT
book-POsS-ACC
'That book of the monk'

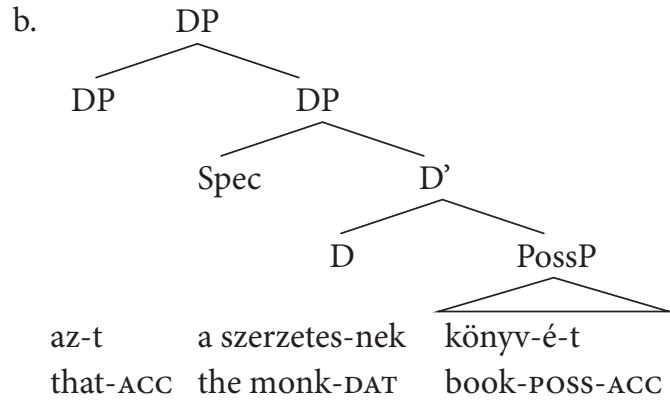

In section 5.3.2, it could be observed how Old Hungarian sources had struggled with translating a phrase from the gospel of Matthew (Matthew 24:14), in which a demonstrative modifier should have been combined with a possessor expression. In the so-called Bible of Vizsoly, compiled in 1590, the problem is, however, practically solved by the application of this new combination:

Matthew 24:14 in the Bible of Vizsoly (1590):

(23) Es predikáltatic ez Isten ország-á-nak Evangeliom-a mind az and be.preached this God kingdom-Poss-DAT gospel-poss all the egész föld-ön

whole land-suP

The question remains how we get to the present-day distribution where, according to the strict word order rule, dative-marked possessors always have to precede demonstrative modifiers. The simultaneous appearance of a demonstrative and a possessor must always have remained infrequent, but simple demonstrative modification is definitely and universally a common construction. At a certain point in the history of the Hungarian language, which cannot be defined in lack of empirical data but must be placed between Middle Hungarian and present-day Hungarian, the position of demonstratives was established in the specifier of the DP. When looking for an 
explanation, one might rely on Van Gelderen's (2008b: 250) third universal economy principle, the so-called 'Specifier Incorporation' principle, that claims for elements coming from outside to tend to be a specifier rather than an adjunct. ${ }^{9}$ In accordance with this principle, the originally adjoined demonstrative phrase must have been integrated into the DP domain, as its behaviour in Modern Hungarian suggests (see section 5.2.1). In this way, the demonstratives' rather atypical nature in the presentday system becomes more reasonable: they appear in a doubly filled DP projection, and their morphology is also somewhat exceptional, since they are marked for case and plurality unlike other modifiers within the Hungarian noun phrase. All these can be due to their appositive origin and to the assumption that, diachronically speaking, they arrived from outside the DP.

However, a final question may be raised: why is it the demonstrative that has become fixed in Spec,DP rather than the possessor expression, as the word orders presented in (19)-(21) would suggest? The answer might be found by considering the different nature of demonstratives and possessors. Whereas demonstratives were (and are always) closely associated with the noun they modify, the option for a dative-marked constituent to be interpreted as an external constituent (with an 'affected' theta-role, cf. É. Kiss 2014), or to be extracted or even completely omitted always remained available. At the same time, of course, in unmarked cases, the possessor appeared adjacent, syntactically adjoined, to the determined noun phrase. After the demonstrative had been integrated into Spec,DP, the target position of the adjoined dative-marked possessors may have been reanalysed as a new layer of the extended noun phrase, namely a Topic projection-in line with what É. Kiss (2000) proposes.

\subsection{Summary}

In this chapter, by studying the determination and the distribution of possessive constructions from Old Hungarian to the present day, a peculiar word order change phenomenon has been accounted for. The grammaticalization of the definite article in well-defined contexts had structural consequences at the nominal left periphery, the most salient of which is the emergence of a new strategy for demonstrative modification. This strategy is called determiner doubling throughout the paper. It has also been observed that the newly added demonstratives first adjoined to the noun phrase in a somewhat looser fashion: their combination with the dative-marked possessors resulted in a word order specific only to the Middle Hungarian period (Dem Poss). Demonstratives, however, at a later stage, got incorporated into the specifier of the DP as the Modern Hungarian fixed word order (Poss Dem) clearly testifies.

\footnotetext{
${ }^{9}$ Van Gelderen, providing a general overview of the DP cycle in several languages (2007, and Chapter 6 in 2011), points out that after the reanalysis of the demonstrative as an article, the renewal of demonstratives may happen in one of the following ways: either from above, by the incorporation of an appositive demonstrative pronoun, or from below, through the addition of a locative adverb. It is to be noted, that reinforced forms of demonstratives (emez, amaz, ezen, azon) also emerged in the history of Hungarian, but today their use is highly limited and stylistically marked. For further discussion, see Egedi (2014a).
} 
The word order variation and the change discussed are summarized in the following schema of the various patterns and their combinations:

(24) Schema of variation and change

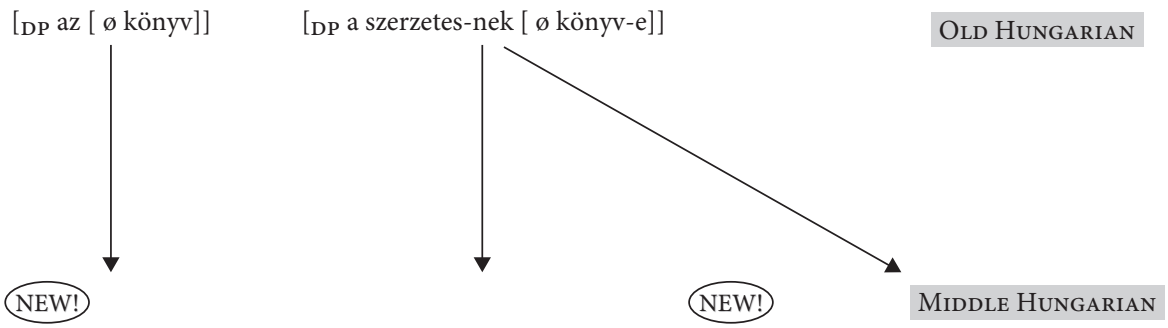

[DP [DP az] [DP a könyv]] [DP a szerzetes-nek [ $ø$ könyv-e]] [DP [DP a szerzetes-nek] [DP a könyv-e]]

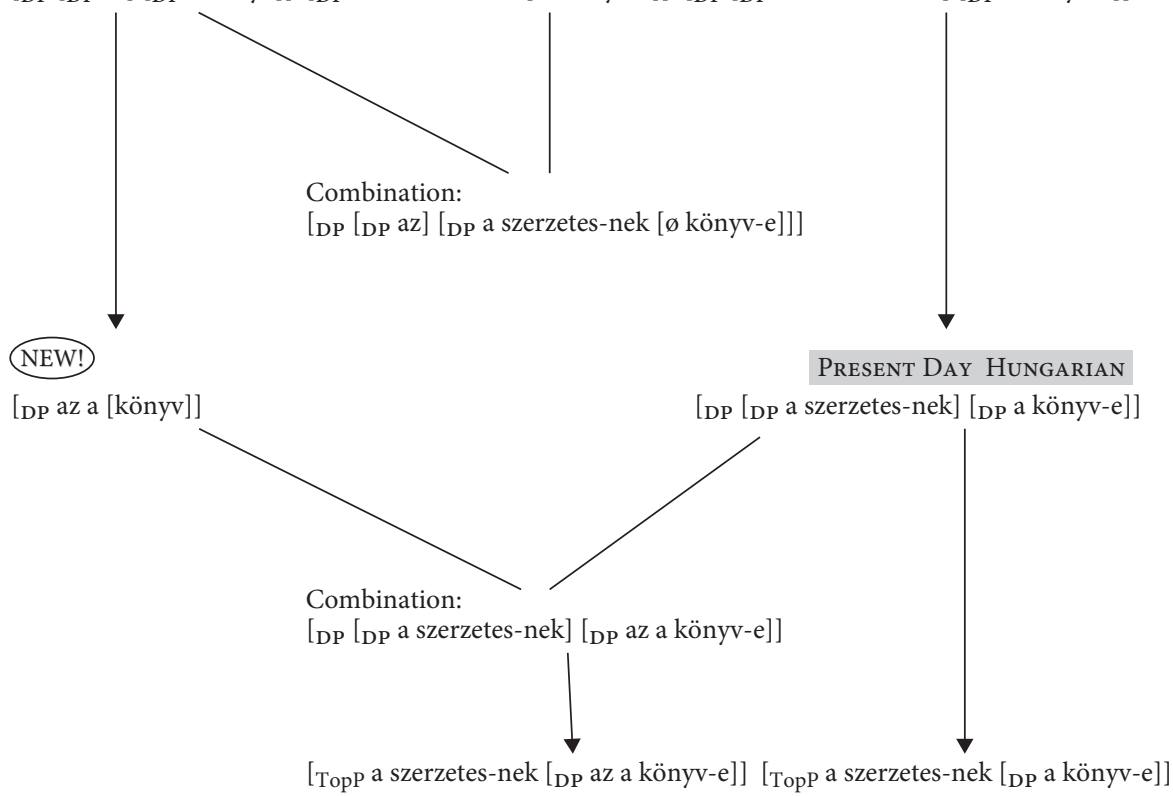

The complex figure in (24) presents how the Old Hungarian patterns without definite article were replaced by new constructions involving adjunction sites for demonstratives and dative-marked possessors. However, as the old possessive construction had still been preserved, its combination with the new determiner doubling strategy produced a word order that did not survive the Middle Hungarian period (see the combination in the centre of the figure). The lower part of the schema shows that the incorporated demonstrative cannot precede the possessive expression any more, and from this point on, dative-marked possessors occupy the outermost position of the extended noun phrase. 


\section{Acknowledgements}

The paper forms part of a complex research project devoted to the study of the diachronic syntax of Hungarian as well as to the building of an online searchable historical language corpus of Old Hungarian. The project has been supported by the Hungarian Scientific Research Fund (OTKA No. 78074 and No. 112828), and the first theoretical results have been summarized in an edited volume, including the contribution of the present author (cf. Egedi 2014a). The focus of the latter book chapter and the present paper considerably differ, but as their topics are closely related, some of the arguments and the data will necessarily overlap.

\section{Sources}

Bible of Vizsoly: Szent Biblia (=The Holy Bible). Translated by Gáspár Károli. Vizsoly, 1590. (Facsimile published by Helikon, Budapest, 1990.)

Faludi: Toldy, Ferenc (ed.): Faludi Ferencz minden munkái (=Collected Works of Ferenc Faludi). Nemzeti Könyvtár, 1853.

Jordánszky Codex: Toldy, Ferenc and György Volf (eds): A Jordánszky-kódex bibliafordítása. (Critical edition of the original Old Hungarian translation from 1516-19) Buda, 1888.

Káldi Preaching: Káldi György: Az innepkre-valo predikatzioknak elsö része. (=Preaching for feast days, Part One) Pozsony, 1631.

Munich Codex: Nyíri, Antal (ed.), Müncheni kódex. (Critical edition of the original codex form 1466, with the corresponding Latin text) Budapest, Akadémiai Kiadó, 1971.

New Testament of Pesti Gábor: Pesti Mizsér Gábor: Új Testamentum magyar nyelven (=The New Testament in Hungarian). Facsimile edition of the original from 1536. Budapest, MTA [2002].

Pázmány Kal.: Pázmány Péter: Kalauz. (=A Guide) Pozsony, 1613. 
Comp. by: Bendict Richard Stage : Proof ChapterID: 0003389062 Date:8/1/18 Time:13:48:53

Comp. by: Bendict Richard Stage : Proof

Dictionary : OUP_UKdictionary 104
\[ \text { OUP UNCORRECTED PROOF - FIRST PROOF, 8/1/2018, SPi } \] 